\title{
SUITABILITY OF THE KOZANI'S AREA (NW MACEDONIA, GREECE) CARBONATE ROCKS FOR THE CEMENT INDUSTRY AND AS AGGREGATES IN CONSTRUCTIONS
}

\author{
Dagounaki C. ${ }^{1}$, Sikalidis C. ${ }^{2}$, Kassoli-Fournaraki A. ${ }^{1}$, and Tsirambides A. ${ }^{1}$ \\ ${ }^{1}$ Department of Mineralogy-Petrology-Economic Geology, School of Geolofy, Aristotle University \\ of Thessaloniki, 541 24, Thessaloniki, dagunaki@geo.auth.gr, kassoli@geo.auth.gr, \\ ananias@geo.auth.gr \\ ${ }^{2}$ Department of Chemistry, School of Chemical Engineering, Aristotle University of Thessaloniki, \\ 541 24, Thessaloniki, sikalidi@eng.auth.gr
}

\begin{abstract}
The suitability of Kozani's broader area carbonate rocks for use in cement production and as aggregates, is studied in terms of their mineralogical, chemical and mechanical characteristics. The studied carbonate rocks belong to the Pelagonian zone and are represented mainly by pure limestones with subordinate dolomites and dolomitic limestones. Examination concerning their insoluble residue, organic matter and milling behavior, together with their mineralogical and chemical composition showed that all carbonate formations of Kozani's broader area, except the dolomitic ones, fulfill the requirements for use as raw material in the cement industry and all the carbonate formations meet the specifications for their use as aggregates in various constructions.
\end{abstract}

\section{INTRODUCTION}

Cement is one of the most important plasters used in constructions. Cement production is the processing of selected and prepared mineral raw materials to produce, through the pyroprocessing, the synthetic mineral mixture (clinker) that can be ground to a powder (flour) having the specified chemical composition and physical properties of cement. These processes are of major economic importance and so have been subjected to considerable studies (Ames et. al., 1994, Manning, 1995).

Portland cement is essentially composed of four main components, namely lime (CaO), silica $\left(\mathrm{SiO}_{2}\right)$, alumina $\left(\mathrm{Al}_{2} \mathrm{O}_{3}\right)$ and iron oxide ( $\mathrm{FeO}$ ) (Manning, 1995, Oates, 1998). In many countries, cement production represents the second largest market for limestone and is exceeded only by the use of limestone in construction and building. Not only because it supplies the necessary chemical compounds, but also because with its addition to portland cement improves several cement properties such as concrete strength and durability (Bertrandy and Poivetin, 1991, Liversey, 1991, Sprung and Siebel, 1991, Cochet and Sorrentino, 1993, Tsivilis et al., 2000). Portland cement reduces the demand of water compared to the relatively pure cements (Tsivilis et al., 2002) and improves the durability of the concrete (Sawicz and Heng, 1996, Zelič et. al., 1999, Vuk et al., 2001, Tsivilis et al., 2002). In addition, as a filler improves physically the denseness of cement composites (Regourd, 1986, Heikal et al., 2000) and the particle packing of the cement system (Ellerbrock et al., 1990, Bonavetti et al., 2001) and reduces the diffusion coefficient of chloride ions (Hornain et al., 1995, Heikal et al., 2000).

The major uses of limestone and dolomite as an aggregate are in concrete and roadstone (both bound and unbound). Other applications include railway track ballast, armourstone for sea defense works, waterway construction, asphalt filler and raw material for mortars. Aggregates provide compressive and tensile strength, surface textures, weight and density, abrasion resistance and must bond well with cement or bitumen binders. They must also meet additional requirements relating to the intended use (not shrink or swell, crack or react once in use). While technical factors such as particle shape, strength and durability are important, the delivered cost is generally a major factor affecting the choice of aggregate (Boynton, 1980, McCarl, 1994, Manning, 1995, Oates, 1998). 
One of the reasons why most of the construction companies prefer limestone instead of other materials, is its widespread formations all over the world.

As technology penetrates thoroughly to the cement manufacture, specifications become more discriminating. The importance of construction and its materials dictates the need for finding raw materials to establish product quality (Ames et al., 1994). This work aims to investigate the suitability of carbonate rocks (limestones, dolomites and dolomitic limestones) from the Kozani broader area for use in cement production and as aggregates in various constructions.

\section{MATERIALS AND METHODS}

\subsection{Geological setting}

The studied samples were collected from the Kozani broader area formations (northwestern Macedonia, Greece), which belong to the Pelagonian zone. Studies upon the petrology and tectonics of the zone have shown it to be a polyphased-deformed continental fragment. It consists of a crystalline pre-Carboniferous basement composed of gneisses, amphibolites and schists that are intruded by large masses of Upper Carboniferous granites. Two separate carbonate covers were deposited on the margins east and west of the Pelagonian zone during the Triassic-Jurassic. The cover of the eastern margin is a neritic carbonate sequence, which thrusted westward onto the Pelagonian crystalline basement in the Late Jurassic-Early Cretaceous. The autochthonous neritic carbonate cover of the western Pelagonian margin was deposited on the Upper Paleozoic metaclastics. Big ophiolitic complexes were obducted on the Triassic-Jurassic carbonate formations of the Pelagonian zone. Ophiolites are overlain by Middle-Upper Cretaceous sediments and Early Paleocene flysch deposits (Mountrakis et al., 1981, Mountrakis, 1984, Mountrakis, 1985, Mountrakis, 1986).

The Pelagonian zone has suffered two metamorphic events. The first one happened before the Carboniferous and affected the crystalline basement in upper greenschist conditions while the second one had post-Jurassic age and resulted in a weak, low-grade greenschist fabric in the Upper Paleozoic and Mesozoic rocks (Nance, 1981, Mountrakis, 1984, Mountrakis, 1986).

\subsection{Sampling and experimental procedures}

Kozani broader area, for easing the sample collection and the research, was devided into four sections: a) the Vermion section, b) the Kozani section, c) the Siatista section and d) the Vourinos section. According to the collection place, the samples were named after the section. So the samples B-SE, B-ME and B-ZP belong to the Vermion section, the samples K-RY, K-DR and K-AM belong to the Kozani section, the samples S-SI and S-MI belong to the Siatista section and the samples BO-BI, BO-TZ, BO-PA1 and BO-PA2 belong to the Vourinos section (Fig. 1).

Thin sections from the collected samples were prepared in order to examine their texture and mineralogical composition. Part of each carbonate sample was ground in an agate mortar for X-ray diffraction and chemical analysis. X-ray diffraction analysis was performed using a Philips diffractometer with $\mathrm{Ni}$-filtered $\mathrm{CuK}_{\mathrm{a}}$ radiation on randomly oriented samples over the interval $3-63^{\circ}$ of $2 \theta$ and at a scanning speed of $1.2 \% \mathrm{~min}$. Semi-quantitative estimation of the percentage of the minerals present in the samples was made using the ASTM cards of International Centre for Diffraction Data (U.S.A.).

Chemical analyses of the rock samples were performed by atomic absorption spectrophotometry (AAS) using a PERKIN-ELMER 5000 apparatus. Ground samples were heated at $550^{\circ} \mathrm{C}$ for two hours in order to remove the organic matter and were treated by a $1 \mathrm{~N} \mathrm{HCl}$ solution for the definition of the insoluble residue and its mineral content. Finally, experiments were conducted in order to determine their milling behaviour. The samples were milled for predetermined periods of time in a Fritsch, centrifugal ball-mill, pulverisette 6 apparatus and their residue on a $250 \mu \mathrm{m}$ sieve was compared. 


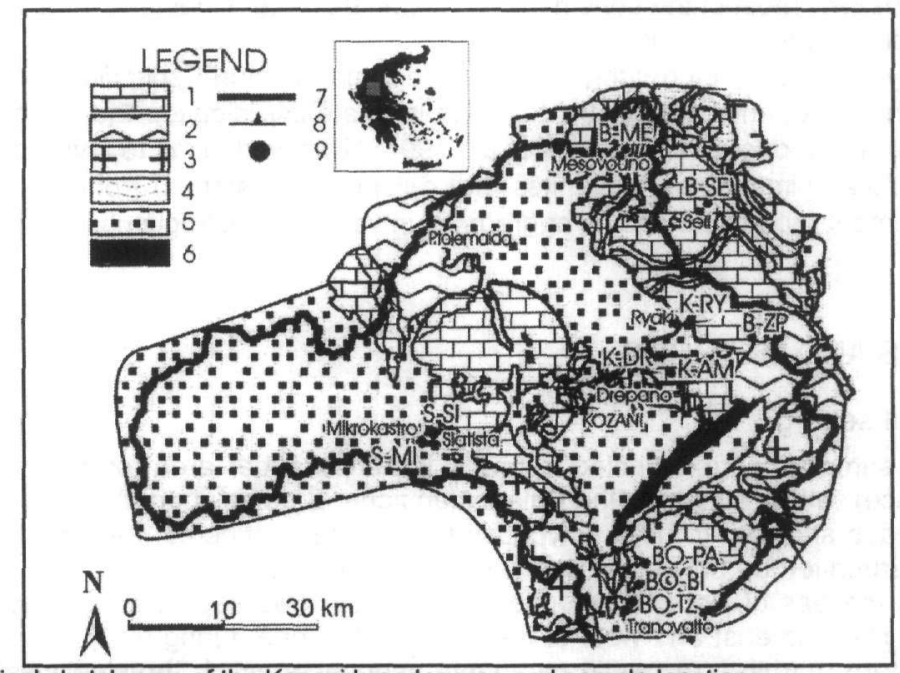

Figure 1. Geological sketch map of the Kozani broader area and sample locations.

1 = Limestones-marbles, 2 = Metamorphic rocks, 3 = Igneous rocks, 4 = Flysch, 5 = Alluvial deposits, $6=$ Polyfytos lake, $7=$ Kozani prefecture borders, $8=$ Obduction, $9=$ Sample locations.

\section{RESULTS AND DISCUSSION}

\subsection{Description of the samples}

Macroscopically, the studied samples display a distinctive variation in color and appearance. Samples S-MI, S-SI, B-SE, B-ME, K-DR are dark gray with white veinlets, samples K-RY and BOPA2 are light gray and samples B-ZP, K-AM, BO-BI, BO-TZ and BO-PA1 are white in color. Microscopic examination of thin sections revealed a coarse-grained holocrystalline texture for $\mathrm{B}-\mathrm{ZP}, \mathrm{K}$ AM, BO-BI, BO-TZ, BO-PA1 and BO-PA2 and a micritic texture for S-MI, B-ME, K-RY. Finally, the S-SI, B-SE, K-DR are consisted of medium and coarse grains, often tectonized (Dagounaki, 2001).

\subsection{Mineralogical composition}

The mineralogical composition of all samples studied (microscopy, $\mathrm{X}$-ray diffraction) is shown in table 1. The majority of them are limestones with the proportion of the calcite ranging between 93$99 \%$. The Vourinos sample BO-PA2 is characterized as dolomitic limestone (calcite $83 \%$ and dolomite $17 \%$ ), while the B-ME from Vermion and the K-RY and K-AM from Kozani are dolomites with dolomite ranging between 92 and $96 \%$. The percentage of impurities (silicates) does not exceed $3 \%$ and is observed in sample B-ME from Vermion formation. 


\begin{tabular}{llllll}
\hline Sample & Calcite & Dolomite & Quartz & Chlorite & Muscovite \\
\hline S-MI & 99 & & 1 & & \\
S-SI & 99 & & 1 & & \\
B-SE & 93 & 6 & 1 & & \\
B-ME & 5 & 92 & & 3 & \\
B-ZP & 99 & & 1 & & \\
K-RY & 4 & 96 & & & \\
K-DR & 99 & & 1 & & \\
K-AM & 5 & 95 & & \\
BO-BI & 99 & & 1 & \\
BO-TZ & 97 & 3 & & \\
BO-PA1 & 97 & & 1 & & \\
BO-PA2 & 83 & 17 & & & \\
\hline
\end{tabular}

\subsection{Chemical composition}

The results of chemical analyses referred to the main oxides (Table 2) are in agreement with the mineralogical composition (see Table 1). The amount of impurities (oxides except $\mathrm{CaO}$ and $\mathrm{MgO}$ ) ranges between 1.14 and $3.22 \%$. The composition of the samples compared to the average limestone composition (Mason and Moore, 1982) confirms the fact that they are very pure materials. Chemical analyses for the amount of trace elements show that only two samples from Vermion (B-SE, B-ME) present higher concentrations of $\mathrm{Cr}$ and all the samples except S-SI, B-ME, K-RY and $\mathrm{K}-\mathrm{AM}$ present higher concentrations of $\mathrm{Ni}$ compared to the average composition given for commercial limestones (Oates, 1998). K-DR from Kozani section presents higher concentration of Co compared to the other samples. These relatively higher concentrations of the above trace elements are attributed to the direct contact of the carbonate formations with the ophiolitic complexes.

Table 2. Chemical composition (wt. \% or ppm) of the Kozani carbonate rocks.

\begin{tabular}{|c|c|c|c|c|c|c|c|c|c|c|c|c|c|}
\hline (wt. \%) & S-MI & S-SI & B-SE & B-ME & B-ZP & K-RY & K-DR & K-AM & $\mathrm{BO}-\mathrm{BI}$ & BO-TZ & BO-PA1 & BO-PA2 & $M \& M$ \\
\hline $\mathrm{SiO}_{2}$ & .54 & 0.70 & 2.41 & 2.14 & 2.14 & 2.41 & 1.88 & 2.41 & 2.94 & 2.67 & 2.67 & 2.14 & 5.19 \\
\hline $\mathrm{Al}_{2} \mathrm{O}_{3}$ & .10 & 0.00 & 0.12 & 0.15 & 0.00 & 0.00 & 0.00 & 0.00 & 0.00 & 0.00 & 0.17 & 0.00 & 0.81 \\
\hline $\mathrm{TiO}_{2}$ & 0.016 & 0.29 & 0.016 & 0.000 & 0.000 & 0.000 & 0.016 & 0.100 & 0.000 & 0.000 & 0.000 & 0.000 & 0.06 \\
\hline MnO & 0.01 & 0.002 & 0.01 & 0.004 & 0.005 & 0.002 & 0.007 & 0.002 & 0.007 & 0.002 & 0.002 & 0.004 & \\
\hline $\mathrm{Fe}_{2} \mathrm{O}_{3} \mathrm{t}$ & .16 & 0.07 & 0.13 & 0.07 & 0.00 & 0.00 & 0.06 & 0.00 & 0.04 & 0.00 & 0.07 & 0.00 & 0.54 \\
\hline $\mathrm{CaO}$ & 54.30 & 55.20 & 51.25 & 31.15 & 54.60 & 31.85 & 53.03 & 30.45 & 52.58 & 53.90 & 52.80 & 49.80 & 42.57 \\
\hline $\mathrm{MgO}$ & .56 & 0.29 & 2.08 & 21.33 & 0.40 & 20.00 & 0.62 & 21.75 & 1.38 & 0.92 & 0.8 & 4.6 & 7.89 \\
\hline $\mathrm{K}_{2} \mathrm{O}$ & 03 & 0.03 & 0.19 & 0.06 & 0.14 & 0.10 & 0.11 & 0.09 & 0.0 & 0.09 & 0.1 & 0.0 & 0.33 \\
\hline $\mathrm{Na}_{2} \mathrm{O}$ & 0.16 & 0.22 & 0.30 & 0.09 & 0.23 & 0.21 & 0.26 & 0.19 & 0.10 & 0.07 & 0.08 & 0.12 & 0.05 \\
\hline $\mathrm{P}_{2} \mathrm{O}_{5}$ & 0.14 & 0.19 & 0.04 & 0.03 & 0.045 & 0.02 & 0.03 & 0.0 & 0.0 & 0.0 & 0. & 0.025 & 0.04 \\
\hline LOI & 43.52 & 43.22 & 43.36 & 44 & 42 & 45.06 & 43.60 & & 1 & & 4 & 42.85 & \\
\hline Total & 9.526 & 100.212 & 99.906 & 99.904 & 99.900 & 99.652 & 99.613 & 99.882 & 99.937 & 99.812 & 99.882 & 99.609 & \\
\hline$(\mathrm{ppm})$ & & & & & & & & & & & & & Oates \\
\hline Co & 28 & 22 & 16 & b.d.l. & b.d.l. & 16 & 46 & b.d.I. & b.d.I. & b.d.I. & 19 & b.d.I. & \\
\hline $\mathrm{Cr}$ & 11 & 12 & 23 & 27 & 15 & 13 & 17 & 15 & 15 & 15 & 15 & 12 & $3-15$ \\
\hline $\mathrm{Ni}$ & 23 & b.d.l. & 28 & b.d.I. & 17 & b.d.I. & 21 & b.d.l. & 21 & 21 & 21 & 17 & $0.5-15$ \\
\hline $\mathrm{Rb}$ & 58 & 60 & 84 & 28 & 64 & 54 & 36 & 24 & 29 & 38 & 38 & 26 & \\
\hline $\mathrm{Sr}$ & 213 & 185 & 358 & 168 & 228 & 153 & 518 & 102 & 440 & 210 & 213 & 250 & \\
\hline $\mathrm{Zn}$ & 17 & 6 & 7 & 13 & 14 & 16 & 5 & 8 & 7 & 6 & 7 & 7 & $3-500$ \\
\hline
\end{tabular}

b.d.I.=below detection limit

M\&M=Average limestone composition (Mason and Moore, 1982)

Oates=Typical ranges of trace elements in commercial limestones (Oates, 1998) 


\subsection{Insoluble residue and organic matter}

Table 3 shows the amount of the amount of the insoluble residue of the samples including organic matter. The residue is low and ranges between 0.09 and $1.73 \%$. It is mainly quartz, chlorite and muscovite with lesser albite. The paragenesis quartz+chlorite+muscovite+albite confirms the greenschist metamorphic phase of the carbonate formations. The organic matter ranges between 0 and $1.07 \%$, being thus within the limits for carbonate rocks (Boynton, 1980).

Table 3. Insoluble residue (\%), mineralogical composition of insoluble residue (wt.\%) and organic matter (\%) of the Kozani carbonate rocks.

\begin{tabular}{lllllll}
\hline Sample & Insoluble residue & Quartz & Chlorite & Muscovite & Albite & Organic matter \\
\hline S-MI & 0.52 & 100 & & & & 0.29 \\
S-SI & 0.16 & 100 & & & 22 & 0.20 \\
B-SE & 0.96 & 61 & 9 & 8 & & 0.28 \\
B-ME & 1.22 & & 100 & & & 0.61 \\
B-ZP & 0.20 & 1 & & 99 & & 0.19 \\
K-RY & 1.73 & 11 & 37 & 52 & & 1.07 \\
K-DR & 0.09 & 100 & & & & 0.20 \\
K-AM & 0.76 & & 52 & 48 & & 1.00 \\
BO-BI & 1.23 & 36 & & 64 & & 0.20 \\
BO-TZ & 0.26 & & & 97 & 3 & 0.00 \\
BO-PA1 & 0.94 & 18 & 16 & 66 & & 0.15 \\
BO-PA2 & 1.03 & & & 100 & & 0.19 \\
\hline
\end{tabular}

\subsection{Milling}

The primary objective of milling is to prepare sizes and mixtures of raw materials for kiln feed that effectively and economically can be processed in the kiln to produce the desired cement (Ames et al., 1994). Table 4 shows the percentage of powder passing the $250 \mu \mathrm{m}$ sieve after milling of the samples in different periods of time.

In figure 2 the effect of the milling time on particle size of the samples is presented. The samples are grouped according to the regions from which they derive. As it is shown, for Siatista samples and the sample B-ZP from Vermion milling time of $105^{\prime \prime}$ is needed to achieve particle size $100 \%<250 \mu \mathrm{m}$. The Vourinos samples need $45^{\prime \prime}-60 "$, while the rest of Vermion samples and the Kozani K-RY need more time than 105" to turn to size smaller than $250 \mu \mathrm{m}$. Especially, the sample B-ME from Vermion is the hardest of the studied carbonate rocks.

Table 4. Percentages (wt. \%) of powder passing through the $250 \mu \mathrm{m}$ sieve for predetermined periods of time (sec) of the Kozani carbonate rocks.

\begin{tabular}{|c|c|c|c|c|c|c|c|c|c|}
\hline Sample & $5^{\prime \prime}$ & $7.5^{\prime \prime}$ & $15^{\prime \prime}$ & $22.5^{\prime \prime}$ & $30^{\prime \prime}$ & $45^{\prime \prime}$ & $60^{\prime \prime}$ & $90^{\prime \prime}$ & $105^{\prime \prime}$ \\
\hline$\overline{\text { S-MI }}$ & & & & & 33.43 & 48.09 & 64.00 & 89.62 & 100.00 \\
\hline S-SI & & & & & 18.23 & 33.82 & 53.83 & 75.45 & 100.00 \\
\hline B-SE & & & & & 21.84 & 23.34 & 25.96 & 73.96 & 80.00 \\
\hline B-ME & & & & & 15.55 & 24.35 & 34.62 & 51.87 & 65.00 \\
\hline B-ZP & & & & & 20.60 & 38.39 & 56.56 & 84.64 & 100.00 \\
\hline K-RY & & & & & 18.87 & 30.04 & 33.91 & 69.30 & 90.00 \\
\hline K-DR & 6.97 & & 22.50 & & 42.02 & 53.50 & 80.00 & & \\
\hline K-AM & & & 18.98 & & 26.95 & 43.93 & 63.10 & 100.00 & \\
\hline $\mathrm{BO}-\mathrm{BI}$ & & 31.16 & 59.69 & 90.90 & 96.96 & 100.00 & & & \\
\hline BO-TZ & & 29.36 & 66.25 & 86.17 & 97.98 & 100.00 & & & \\
\hline BO-PA1 & 20.57 & & 34.96 & & 72.85 & 95.79 & 100.00 & & \\
\hline BO-PA2 & 13.28 & & 23.01 & & 40.35 & 53.45 & 100.00 & & \\
\hline
\end{tabular}



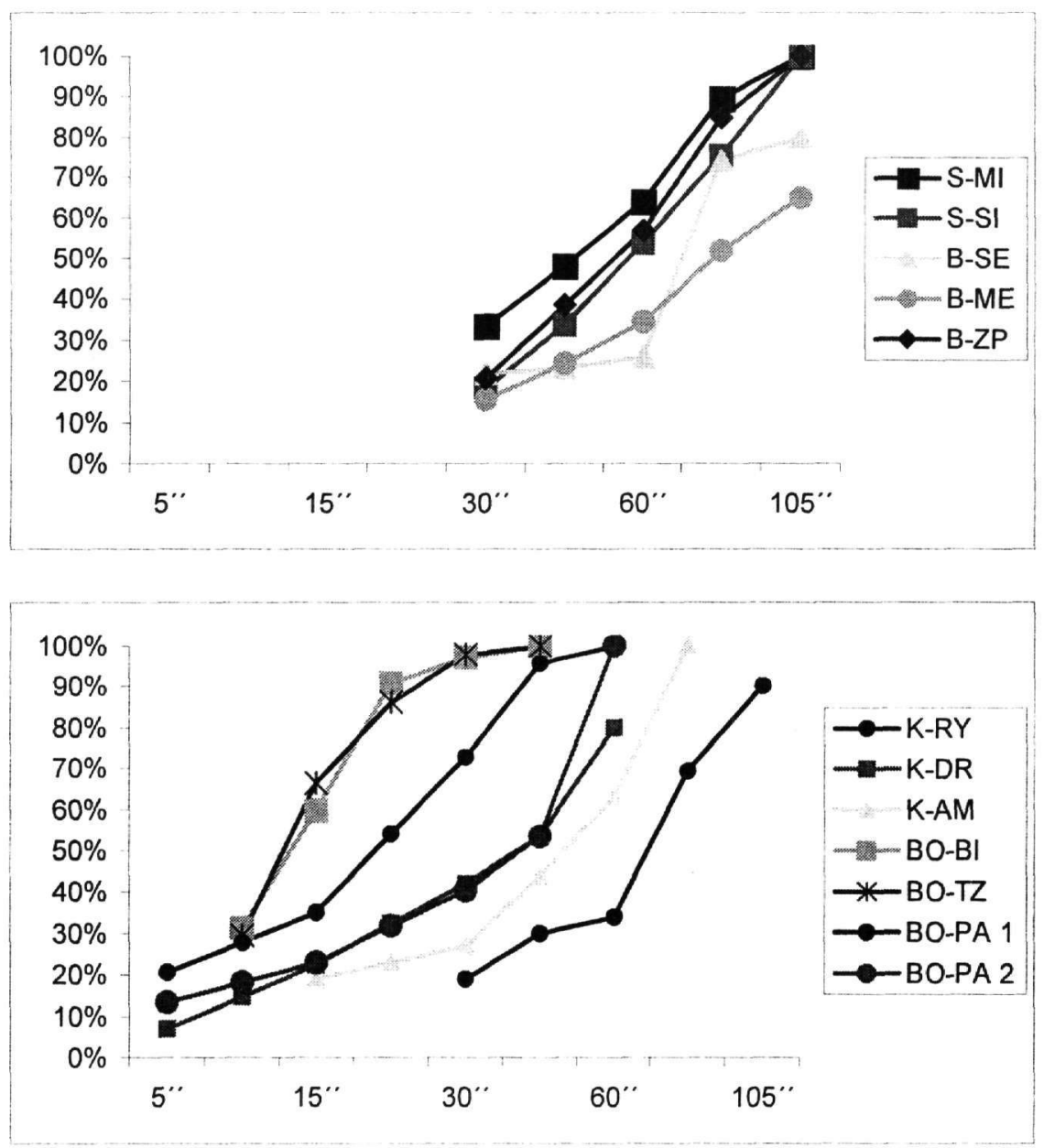

Figure 2. Effect of milling time on particle size of the Kozani carbonate rocks.

\subsection{Suitability for cement production}

The composition of a typical cement kiln feed is shown in table 5 . Magnesium carbonate is the main undesirable impurity. The level of $\mathrm{MgO}$ in the clinker should not exceed $5 \%$. Other manufacturers have established the stricter limit of $3 \%$ (Oates, 1998). The $\mathrm{MgO}$ is avoided because during burning periclase is formed, which hydrates after setting and expands (Ames et al., 1994, Manning, 1995). Other restrictions are the phosphorus content $(<0.2 \%)$ and the alkalies content (Ames et. al., 1994), which could enhance reactions with amorphous silica in aggregates (Manning, 1995). The insoluble residue should also be lower than $1.5 \%$ (Harben, 1992).

Table 5. Analysis of a typical cement kiln feed (Oates, 1998, Harben, 1992).

\begin{tabular}{ll}
\hline Components & Analysis $\% \mathrm{~m} / \mathrm{m}$ \\
\hline $\mathrm{CaO}$ & 44.4 \\
$\mathrm{MgO}$ & $\leq 5$ \\
$\mathrm{SiO}_{2}$ & 14.3 \\
$\mathrm{Al}_{2} \mathrm{O}_{3}$ & 3 \\
$\mathrm{Fe}_{2} \mathrm{O}_{3}$ & 1.1 \\
$\mathrm{~F}$ & $\leq 0.1$ \\
Total insoluble & $\leq 1.5$ \\
Loss on ignition & 35.9 \\
\hline
\end{tabular}


Comparing the chemical analyses of the Kozani carbonate samples with the specified requirements, it can be said that:

- The dolomitic samples B-ME, K-RY and K-AM, from Vermion and Kozani, cannot be used in cement production.

- In all the suitable samples for cement production the concentration of $\mathrm{SiO}_{2}$ is $<3 \%$. The highest amounts of $\mathrm{SiO}_{2}$ were observed in the Vourinos samples with proportions ranging between 2.14-2.94\%.

- The content of $\mathrm{Fe}_{2} \mathrm{O}_{3}$ (total) and $\mathrm{Al}_{2} \mathrm{O}_{3}$ is very low. In the majority of the samples no $\mathrm{Al}_{2} \mathrm{O}_{3}$ was detected while three samples (B-ZP, BO-TZ, BO-PA2) do not contain any $\mathrm{Fe}_{2} \mathrm{O}_{3}$ t. In such cases, raw materials must be added to provide the elements $\mathrm{Fe}$ and $\mathrm{Al}$ for reaching the desirable chemical composition of the clinker.

- The content of the samples in alkalis is pretty low. It ranges between 0.13-0.42 staying always below $0.5 \%$.

- The amount of the insoluble residue in the suitable for cement production samples is lower than $1.5 \%$, thus it isn't a prohibitive factor for their use.

- It is known that the grain size is an important factor to the cement performance and affects many properties of clinker. Performing the milling experiment, it is revealed that the Kozani carbonate rocks are ground in a very short time period and the desirable size is approached in a few minutes.

- An important number of studies have been done on how the presence of some elements (such as $\mathrm{Zn}, \mathrm{Ni}, \mathrm{Cr}$, etc) affects the formation of clinker, the hydration and the performance of mortars and concrete. Because of their low concentrations, trace elements of the studied samples have no influence on the process of burning or the hydration process. The experiments have shown that low concentrations (less than $0.5 \% \mathrm{wt}$ ) don't affect the performance of cement (Murat and Sorrentino, 1996, Stephan et. al., 1999, Frias and Sánchez de Rojas, 2002).

- The suitable for cement production Kozani carbonate rocks can, also, be added as fillers in Portland cement, as they can affect many of its properties. Of course, the effect of limestone addition depends on clinker type and the fineness of the cement (Heikal et al., 2000, Bonavetti et al., 2001, Vuk et al., 2001, Tsivilis et al., 2002).

\subsection{Suitability for constructions and building}

The main requirement for the utilization of a material as an aggregate is the size gradation and the uniformity of the particle size. Depending on the application the aggregates are going to be used for, many countries have set certain specifications containing requirements for particle shape, grading, cleanliness and mechanical properties. For example, the "flaky" or "elongated" particles are undesirable in concrete manufacture because they affect the workability and mobility of wet concrete and tend to reduce the strength of the hardened concrete. The same particle shape is required for unbound aggregates for roads. For sand for mortars, the particle shape is needed to be round or cubical. The main undesirable mineral impurities are clay, organic matter, iron pyrites, salts, shale and mica (Boynton, 1980, McCarl, 1994, Manning, 1995, Oates, 1998).

Comparing the above specifications to the results of the milling experiments, it can be said that all the samples from the Kozani broader area can be used in constructions and building, as they can be ground in a very short time, they can provide the desirable for each application size distribution and the shape of their particles is not flaky or elongated but round (investigated by the use of SEM). Finally, the percentage of their insoluble residue is very low so the minerals contained in it, are in very small quantities inside the rock and they don't affect the suitability of the samples as aggregates.

\section{CONCLUSIONS}

1. The carbonate rocks of Siatista, Vermion (except the B-ME), Vourinos and the K-DR sample from Kozani can be used as raw materials in cement industry, as they fulfill the chemical specifications.

2. These carbonate rocks can also be added as cement filler because they positively affect many cement properties. 
Finally, all the samples from the Kozani broader area can be used as aggregates in the construction and building industries.

\section{REFERENCES}

Ames, J.A., Cutcliffe, W.E., and MacFadyen, J.D., 1994. Cement and cement raw materials. In D.D. Carr (S. ed.), Industrial minerals and rocks. 295-316, Littleton, Society for Mining, Metallurgy and Exploration, Inc. $1196 \mathrm{pp}$.

Bertrandy, R. and Poitevin, P., 1991. Limestone filler for concrete, French research and practice. In R.N. Swamy (ed.), Blended Cements in Construction. 16-31, London, Elsevier, 215 pp.

Bonavetti, V.L., Rahhal, V.F., and Irassar, E.F., 2001. Studies on the carboaluminate formation in limestone filled-blended cements, Cem Concr Res, 31, 853-859.

Boynton, S.R., 1980. Chemistry and Technology of Limestone, $2^{\text {nd }}$ edition, New York, Wiley \& Sons, $577 \mathrm{pp}$.

Cochet, G. and Sorrentino, F., 1993. Limestone filled cements: Properties and Uses. In S.L. Sarkar and S.N. Ghosh (eds.), Mineral Admixtures in Cement and Concrete. 266-295. New Delhi, ABI Books, 375pp.

Dagounaki, C., 2001. Mineralogical and geochemical characteristics of carbonate rocks from Kozani areas, Macedonia, Greece, and investigation of their capability for application in industry, MSc Thesis, Thessaloniki, Aristotle University of Thessaloniki, 108pp (in Greek).

Ellerbrock, H.G., Sprung, S., and Kuhlmann, K., 1990. Particle size distribution and properties of cement: Part III. Influence of grinding process, Zem-Kalk-Gips, 43 (1), 13-19.

Frias, M. and Sánchez de Rojas, M. I., 2002. Total and soluble chromium, nickel and cobalt content in the main materials used in the manufacturing of Spanish commercial cements, Cem Concr Res, 32, 435-440.

Harben, P.W., 1992.The industrial minerals handybook, London, Ind. Miner. Div., Metal Bull. PLC, 148pp.

Heikal, M., El-Didamony, H., and Morsy, M.S., 2000. Limestone-filled pozzolanic cement, Cem Concr Res, 30 , 1827-1834.

Hornain, H., Marchand, J., Duhot, V., and Regourd, M., 1995. Diffusion of chloride ions in limestone filler, Cem Concr Res, 25, 1667-1678.

Livesey, P., 1991. Performance of limestone-filled cements. In R.N. Swamy (ed.), Blended Cements in Construction. 1-15, London, Elsevier, 215pp.

Manning, P.A.C., 1995. Introduction to industrial minerals, U.K., Chapman and Hall, 276pp.

Mason, B. and Moore, C.B., 1982. Principles of geochemistry, New York, J. Wiley \& Sons, 344pp.

McCarl, H.N., 1994. Aggregates: Markets and uses. In D.D. Carr (S. ed.), Industrial minerals and rocks. 287293, Littleton, Society for Mining, Metallurgy and Exploration, Inc. 1196pp.

Mountrakis, D., 1984. Structural evolution of the Pelagonian Zone in Northwestern Macedonia. In J. Dixon (ed), The geological evolution of the eastern Mediterranean. 581-590, Oxford, Special Publications of the Geological Society No. 17, Blackwell Scientific Publications, $848 \mathrm{pp}$.

Mountrakis, D., 1985. Geology of Greece, Thessaloniki, University Studio Press, 207pp (in Greek).

Mountrakis, D., 1986. The Pelagonian zone in Greece: a polyphase-deformed fragment of the Cimmerian continent and its role in the geotectonic evolution of the Eastern Mediterranean, J Geology, 94, 335-347.

Mountrakis, D., Sapountzis, E., Kilias, A., Eleftheriadis, G., and Christofides, G., 1983. Paleogeographic conditions in the western Pelagonian margin in Greece during the initial rifting of the continental area, Can J Earth Sci, 20, 1673-1681.

Murat, M. and Sorrentino, F., 1996. Effect of large additions of $\mathrm{Cd}, \mathrm{Pb}, \mathrm{Cr}, \mathrm{Zn}$ to cement raw meal on the composition and the properties of the clinkers and the cement, Cem Concr Res, 26(3), 377-385.

Nance, D., 1981. Tectonic history of a segment of the Pelagonian zone, northeastern Greece, Can J Earth Sci, $18,1111-1126$.

Oates, J.A.H., 1998. Lime and limestone. Chemistry and Technology, Production and Uses, Weinheim, Wiley$\mathrm{VCH}, 455 \mathrm{pp}$.

Regourd, M., 1986. Special cements with additions, Proc. of the 8th Congress on the Chemistry of Cements, Rio de Janeiro, 119-229.

Sawicz, Z. and Heng, S.S., 1996. Durability of concrete with addition of limestone powder, Mag Concr Res, 48, $131-137$.

Sprung, S. and Siebel, E., 1991. Assessment of the suitability of limestone for producing Portland cement (PKZ), Zem-Kalk-Gips, 44, 1-11.

Stephan, D., Maleki, H., Knofel, D., Eder, B., and Hardtl, R., 1999. Influence of Cr, Ni and $\mathrm{Zn}$ on the properties of pure clinker phases: Part I. C 3 S, Cem Concr Res, 29, 545-552.

Tsivilis, S., Batis, G., Chaniotakis, E., Grigoriadis, Gr., and Theodossis, D., 2000. Properties and behavior of limestone cement concrete and mortar, Cem Concr Res, 30,1679-1683.

Tsivilis, S., Chaniotakis, E., Kakali, G., and Batis, G., 2002. An analysis of the properties of Portland cements and concrete, Cem Concr Com, 24 371-378. 
Vuk, T., Tinta, V., Gabrovšek, R., and Kaučič, V., 2001. The effects of limestone addition clinker type and fineness on properties of Portland cements, Cem Concr Res, 31, 135-139.

Zelič, J., Krstulović, R., Tkalčec, E., and Krolo, P., 1999. Durability of the hydrated limestone-silica fume Portland cement mortars under sulfate attack, Cem Concr Res, 29, 819-826. 